\title{
Incidence of antibodies to native and denatured cartilage collagens (types II, IX, and XI) and to type collagen in rheumatoid arthritis
}

\author{
K MORGAN ${ }^{1}$ R B CLAGUE, ${ }^{1}$ I COLLINS, ${ }^{1}$ SHIRLEY AYAD, ${ }^{2}$ \\ SHIRLEY D PHINN, ${ }^{1}$ AND P J L HOLT ${ }^{1}$
}

From the Departments of ${ }^{1}$ Rheumatology and ${ }^{2}$ Biochemistry and Molecular Biology, University Manchester Medical School, Oxford Road, Manchester

SUMMARY The frequencies of antibodies to the cartilage type IX and XI collagens and to type $\overrightarrow{\vec{T}}$ collagen were determined in 188 patients with rheumatoid arthritis, of whom 76 were positive foP antibodies to native type II collagen. A higher proportion of patients with antibodies to nativo type II collagen had antibodies to these other collagens, but about one third of patients without antibodies to native type II collagen had antibodies to one or more denatured collagens. Th民 patterns of antibodies present in individual sera suggested that there was a selective response t\& the collagens in an individual patient. The incidence of patients having antibodies to these native and denatured collagens in a random group of patients with rheumatoid arthritis was calculated

Antibodies to native type II collagen occur in the sera and synovial fluids of some patients with rheumatoid arthritis (RA). ${ }^{1-6}$ Type II collagen is restricted to a few tissues such as cartilage, vitreous humour, and intervertebral discs as compared with the more universal distribution of type I and III collagens. Thus immunity to type II collagen is of particular relevance in the chronic inflammatory arthritides where destruction of articular cartilage occurs.

Immunity to native type II collagen has been linked to the induction of an inflammatory arthritis in rats and mice. ${ }^{7-12}$ Some features resemble RA. ${ }^{13}$ Also we have shown that type XI $(1 \alpha 2 \alpha 3 \alpha)$ collagen, another cartilage collagen isolated from human articular and bovine nasal cartilage ${ }^{14}{ }^{15}$ can be immunogenic and arthritogenic in rats. ${ }^{16}$ Several short chain, disulphide bonded collagens have been isolated from cartilaginous tissues, ${ }^{17}$ but all are now known to be derived from the same larger molecule, type IX collagen. ${ }^{18}$

We have therefore investigated whether antibodies to type IX and XI collagens occur in patients with RA and whether they are linked to the presence of antibodies to native type II collagen.

Accepted for publication 22 May 1987.

Correspondence to Dr K Morgan, Department of Rheumatology, University of Manchester Medical School, Oxford Road, Manchester M13 9PT.
Similarly, we have investigated whether antibomes to type I, a non-cartilage collagen, found in tendonss synovial tissue, bone, and skin, also occur. Fron these data we have calculated the incidence of patients with RA having antibodies to these nativg and denatured collagens.

\section{Patients and methods}

\section{PAT I E N TS}

The 188 patients were outpatients or inpatients of the Royal Devonshire Hospital, Buxton; of Noble Hospital, Douglas, Isle of Man; of the Rheumar tology Department, Withington Hospital, Mancheste or of the Rheumatology Department, Manchester Royal Infirmary. All patients had definite or class cal rheumatoid arthritis and were chosen for th presence or absence of anti-native type II collagent. antibodies irrespective of their age, sex, or of theigs disease duration or severity.

Control sera were obtained from 90 norma healthy subjects attending the Regional Blood Transfusion Service.

\section{B L OOD SAMPLES}

Blood was collected, allowed to clot at room temperature, and centrifuged at $1500 \mathrm{~g}$ for seven minutes. The serum was removed and frozen a? aliquots at $-20^{\circ} \mathrm{C}$ until used. 
COLLA GENS

Acid soluble native type I collagen was extracted from fetal calf skin and purified by the method of Jackson and Cleary. ${ }^{19}$ Native bovine type II collagen was extracted from nasal septa by pepsin digestion after prior treatment with $2 \mathrm{M}$ magnesium chloride

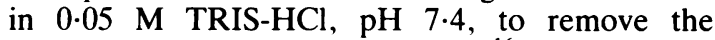
proteoglycans, and purified further. ${ }^{16}$ Native IX and XI collagens were extracted from fetal bovine articular cartilage by similar methods and extensively purified by differential salt precipitation and by dialysis against phosphate buffer. ${ }^{15} 20$

The collagens were stored at $-20^{\circ} \mathrm{C}$ until used. Acid soluble type I collagen was dissolved at 2 $\mathrm{mg} / \mathrm{ml}$ in $0.1 \mathrm{M}$ acetic acid and dialysed into $0.45 \mathrm{M}$ sodium chloride/0.02 M TRIS buffer, $\mathrm{pH} 7 \cdot 5$, before use. The other collagens were dissolved directly in the sodium chloride/TRIS buffer at the same concentration. They were diluted in the same buffer to $10 \mu \mathrm{g} / \mathrm{ml}$ for coating the plates in the anticollagen antibody assay (see below). To denature the collagens the solutions of collagens were heated in a water bath at $46^{\circ} \mathrm{C}$ for 20 minutes immediately before use.

\section{ANTICOLLAGEN ANTIBODIES}

Antibodies to specific collagens were measured in the sera by a solid phase, double antibody, enzyme labelled immunoassay. Linbro 96 well ELISA (enzyme linked immunosorbent assay) plates were coated overnight at $4^{\circ} \mathrm{C}$ with $200 \mu \mathrm{l} /$ well of a 10 $\mu \mathrm{g} / \mathrm{ml}$ solution of collagen in $0.45 \mathrm{M}$ sodium chloride/0.02 M TRIS buffer, $\mathrm{pH} \mathrm{7.5.} \mathrm{The} \mathrm{pro-}$ cedure was the same for both native and denatured collagens. Control plates were coated with $200 \mu \mathrm{l}$ of $0.1 \%(w / v)$ bovine serum albumin in phosphate buffered saline containing $0.05 \%$ (w/v) Tween 20 , pH 7.5 (BSA/PBS/Tween). After washing six times with phosphate buffered saline, $\mathrm{pH} 7 \cdot 5$, containing $0.05 \%$ (w/v) Tween 20 (PBS/Tween) the remaining binding sites in the wells were blocked with $300 \mu \mathrm{l}$ of BSA/PBS/Tween for four hours at room temperature. After washing the plates six times with PBS/Tween the sera diluted 100 times in BSA/PBS/ Tween were added to the wells $(200 \mu \mathrm{l})$ in duplicate. The plates were left overnight at $4^{\circ} \mathrm{C}$ and then washed six times with PBS/Tween. The second antibody (200 $\mu \mathrm{l} /$ well), which was alkaline phosphatase labelled, was added at a dilution of 1:2000 in BSA/PBS/Tween. After four hours at room temperature the plates were washed six times in PBS/ Tween and six times in distilled water.

The substrate, $p$-nitrophenyl phosphate (Sigma 104), was added ( $200 \mu \mathrm{l} /$ well) at a concentration of $1 \mathrm{mg} / \mathrm{ml}$ in $10 \%$ diethanolamine buffer, $\mathrm{pH} 9 \cdot 8$. The reaction was stopped by the addition of $50 \mu \mathrm{l} /$ well of
$3 \mathrm{M}$ sodium hydroxide and the developed colour read at $405 \mathrm{~nm}$ on a Titertek MC densitometer.

Each plate had wells containing BSA/PBS/Tween instead of serum as a blank for non-specific binding of the second antibody and background colour of the reagents. The mean absorbance value for the blank was subtracted from the mean absorbance value for each sample on the same plate. The level of binding to each collagen was then determined by subtraction of the resultant value of each sample on a BSA/PBS/Tween coated plate from the mean of the same sample on the collagen coated plate. The results were expressed as arbitrary units between 0 and 1900 (maximum measurable absorbance being 2000 before subtraction of blank).

\section{Screening assay}

Samples of one date for each of the 188 patients with RA and of the 90 blood donors were screened in one assay for antibodies to native type I, II, IX, and XI collagens. Each plate in the assay had 15 control sera and 32 patients' sera on it. Antihuman IgGAM (DAKO Ltd) was used as the second antibody. The assay was repeated using denatured collagens.

\section{Class of anticollagen antibodies}

Samples of one date for each of 30 sera from patients with RA that were positive for antibodies to native type II collagen were tested for IgG, IgA, or IgM antibodies to native and denatured type II and XI collagens separately in one assay. The second antibodies were antihuman IgG, anti-IgA, or antiIgM (DAKO Ltd).

\section{S T A T I S T I CS}

Antibodies to different antigens were tested for correlation by the Spearman rank correlation coefficient test.

\section{Results}

ANTIBODIES TO NATIVE COLLAGENS

The mean absorbance value of the 90 donors was 22

Table 1 Incidence of sera containing antibodies which bind to native type I, IX, or XI collagens in the three groups tested

\begin{tabular}{|c|c|c|c|}
\hline Collagen & $\begin{array}{l}\text { Donors } \\
(n=90)\end{array}$ & $\begin{array}{l}R A \text { anti-native } I I \\
\text { negative } \\
(n=I 12)\end{array}$ & $\begin{array}{l}R A \text { anti-native } I I \\
\text { positive } \\
(n=76)\end{array}$ \\
\hline Native I & $1^{*}(1 \cdot 1) \div$ & $1(0.9)$ & $9(11 \cdot 8)$ \\
\hline Native IX & $1 \quad(1 \cdot 1)$ & $2(1.8)$ & $3(3.9)$ \\
\hline Native XI & $0 \quad(0)$ & $2(1 \cdot 8)$ & $9(11 \cdot 8)$ \\
\hline
\end{tabular}

${ }^{*}$ Number of samples above the mean plus three standard deviations of the blood donor group (normal controls) for that particular antigen.

+Percentage positive sera. 
units (standard deviation 15.2 units) when using the anti-IgGAM antibody with native bovine type II (NBII) collagen. When three standard deviations above this mean value were taken (i.e., 67.6 units), 88 of these 90 normal sera $(97.8 \%)$ were below this value. With the patients' sera 76 were above this value (anti-NBII positive patients) and 112 were below (anti-NBII negative patients). This, of course, does not reflect the incidence in a random RA group, in which about $10 \%$ of the patients would be positive (personal observations). The mean absorbance value of the 112 anti-NBII negative patients was 22.7 (SD 13.6) units. The 76 antiNBII positive patients had values ranging from 71 to 1095 units (median value $216 \cdot 5$ ).

The incidence of antibodies to native type I collagen (a non-cartilage collagen) and to native type IX and XI collagens (minor cartilage collagens) is shown in Table 1 for the three groups. The levels of antibody to these other collagens are shown in Table 2. Sera from patients with RA who had antibodies to native type II collagen had the highest incidence of antibodies to the other native collagens.

Table 2 Levels of the antibodies to the native collagens (types $I, I X$, and XI) in the positive sera shown in Table $I$

\begin{tabular}{|c|c|c|c|c|}
\hline \multirow[t]{2}{*}{ Serum } & \multicolumn{4}{|c|}{ Native antigens } \\
\hline & $I$ & $I X$ & $X I$ & $I I$ \\
\hline Upper limit of normal & $83 \cdot 8$ & $109 \cdot 8$ & $129 \cdot 6$ & $67 \cdot 6$ \\
\hline \multicolumn{5}{|l|}{ Normal sera } \\
\hline A & $-^{*}$ & 147 & - & - \\
\hline B & 122 & - & - & - \\
\hline C & - & - & - & 71 \\
\hline D & - & - & - & 90 \\
\hline \multicolumn{5}{|c|}{ RA patients anti-II negative } \\
\hline A & 99 & 122 & 150 & - \\
\hline B & - & 220 & 201 & - \\
\hline \multicolumn{5}{|c|}{ RA patients anti-II positive } \\
\hline A & 98 & - & - & 184 \\
\hline B & 98 & - & - & 409 \\
\hline $\mathrm{C}$ & 100 & - & - & 157 \\
\hline D & 123 & 137 & 131 & 358 \\
\hline $\mathrm{E}$ & 127 & - & - & 303 \\
\hline $\mathbf{F}$ & 130 & - & - & 152 \\
\hline G & 136 & - & - & 155 \\
\hline $\mathbf{H}$ & 460 & - & - & 72 \\
\hline I & 888 & - & - & 162 \\
\hline $\mathbf{J}$ & - & - & 132 & 595 \\
\hline $\mathbf{K}$ & - & - & 135 & 189 \\
\hline $\mathrm{L}$ & - & - & 149 & 505 \\
\hline $\mathbf{M}$ & - & - & 155 & 314 \\
\hline $\mathbf{N}$ & - & 143 & 197 & 224 \\
\hline $\mathbf{O}$ & - & - & 235 & 1095 \\
\hline $\mathbf{P}$ & - & - & 256 & 465 \\
\hline $\mathbf{Q}$ & - & 335 & 577 & 650 \\
\hline
\end{tabular}

*The dash (-) indicates below the mean of normals plus three standard deviations (i.e., below the upper limit of normal).
Table 3 Incidence of sera containing antibodies whic? bind to denatured type $I, I I, I X$, or XI collagens

\begin{tabular}{|c|c|c|c|}
\hline Collagen & $\begin{array}{l}\text { Donors } \\
(n=90)\end{array}$ & $\begin{array}{l}R A \text { anti- } \\
\text { native II } \\
\text { negative } \\
(n=I I 2)\end{array}$ & 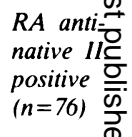 \\
\hline None & $85(94 \cdot 5)^{*}$ & $77(68 \cdot 8)$ & $3 \quad 3.9 \%$ \\
\hline Denatured I & $1(1 \cdot 1)$ & $15(13.4)$ & $27(35.5 \%$ \\
\hline Denatured II & $1 \quad(1 \cdot 1)$ & $20(17 \cdot 9)$ & $71(93.4)$ \\
\hline Denatured IX & $1 \quad(1 \cdot 1)$ & $4(3.6)$ & $9(11.8)^{\rho}$ \\
\hline Denatured XI & $2 \quad(2 \cdot 2)$ & $16(14 \cdot 3)$ & $30(39 \cdot 5 \overline{\mathrm{L}}$ \\
\hline
\end{tabular}

The 17 patients with RA who were positive fo $\vec{\pi}$ antibodies to native type II collagen and also positive for other native collagens fell into twou distinct groups. One group showed low to hige levels of antibodies to native type I collagen (sera A-I) and the other group low to high levels of antibodies to type XI collagen (sera J-Q). The leve of these other antibodies was unrelated to the leve of anti-type II collagen antibody. Also the other 5 黑 anti-NBII positive patients had levels of bindingte native type II collagen from 71 to 842 units but no antibodies to the other native collagens.

ANTIBODIES TO DENATURED COLLAGENS The number of sera having antibodies to the denatured collagens is shown in Table 3, and the pattern of binding is shown in Table 4. Only five o申 the 90 sera from the blood donors showed an $\vec{\not}$ binding to the denatured collagens, and this was at low levels only. In the two groups of patients wit RA there was a higher incidence of sera containing. antibodies binding to the denatured collagenso About $1 / 3$ of the sera from the RA patient group? who had no antibodies to native type II collagen had antibodies to one or more of the denature collagens. There were similar frequencies of ant bodies to denatured type I, II, and XI collagens wit a much lower frequency of antibodies to denature type IX collagen. From Tables 3 and 4 it can be see that many sera contained antibodies to more that one type of denatured collagen.

Seventy three of the 76 sera from the anti-NBI positive patients had antibodies to denatured cofr lagens. Seventy one of these had antibodies $t_{0}^{\circ}$ denatured type II collagen either alone (36 sera) of in combination with antibodies to other denatureq collagens ( 35 sera). There was a correlation betwee the level of antibodies to native and denatured type II collagens in the 71 sera $(\varrho=0.69, p<<0.02) \delta$ Thirty sera had antibodies to denatured type Xक collagen, and all but one of these had antibodies to 
Table 4 Pattern of binding to denatured collagens shown by sera

\begin{tabular}{|c|c|c|c|}
\hline Collagen & $\begin{array}{l}\text { Donors } \\
(n=90)\end{array}$ & $\begin{array}{l}R A \text { anti-native } I I \\
\text { negative }(n=112)\end{array}$ & $\begin{array}{l}R A \text { anti-native II } \\
\text { positive }(n=76)\end{array}$ \\
\hline Denatured II only & $1(1 \cdot 1)^{*}$ & $7(6 \cdot 3)$ & $36(47 \cdot 4)$ \\
\hline Denatured I only & $1(1 \cdot 1)$ & $3(2 \cdot 7)$ & $1(1 \cdot 3)$ \\
\hline Denatured IX only & $1(1 \cdot 1)$ & $3(2 \cdot 7)$ & 0 \\
\hline Denatured XI only & $2(2 \cdot 2)$ & $9(8 \cdot 0)$ & 0 \\
\hline Denatured II and I & 0 & $6(5 \cdot 4)$ & $5 \quad(6 \cdot 6)$ \\
\hline Denatured II and IX & 0 & $1(0 \cdot 9)$ & $1(1 \cdot 3)$ \\
\hline Denatured II and XI & 0 & $1(0.9)$ & $7 \quad(9 \cdot 2)$ \\
\hline Denatured I and XI & 0 & 0 & $1(1 \cdot 3)$ \\
\hline Denatured II, I and XI & 0 & $5(4 \cdot 5)$ & $14(18.4)$ \\
\hline Denatured II, IX and XI & 0 & 0 & $2(2 \cdot 6)$ \\
\hline All four denatured antigens & 0 & 0 & $6 \quad(7 \cdot 9)$ \\
\hline
\end{tabular}

*Values are number of sera (\%).

denatured type II collagen. The levels of antibodies to denatured type II collagen in the patients' sera were correlated with the levels of antibodies to denatured type XI $(\varrho=0.67, p<<0.02)$ but not to denatured type I collagen $(\mathrm{Q}=0 \cdot 25, \mathrm{p}=0.04)$. No patient in this group had antibodies only to denatured type XI, whereas in the anti-NBII negative group nine sera had antibodies only to denatured type XI collagen.

Table 5 shows the levels of antibodies to the different denatured collagens in the sera. The highest levels of antibodies to denatured type I and II collagen were seen in the anti-NBII positive patients. There was little difference between the groups in the levels of antibodies to denatured IX or to denatured XI collagens, but the highest level to denatured type IX collagen was seen in the antiNBII positive group.

\section{ESTIMATED INCIDENCE OF SERA HAVING}

\section{ANTICOLLAGEN ANTIBODIES}

In a group of 100 sera taken from patients with RA at random 10 would be expected to have antibodies to native type II collagen and 90 would be negative (personal observations). Using the above results, we can calculate the expected incidence of sera with antibodies to each of the individual native or denatured collagens (Table 6).

Many patients' sera, of course, will fall into more than one group. Thus we can calculate that of 100 patients with RA, 62 would have no antibodies to these native or denatured collagens, 26 patients would have antibodies to one or more denatured collagen only (I, II, IX, XI), two would have low levels to native type IX, XI and/or type I collagens with antibodies to these denatured collagens too, five would have antibodies to native and denatured type II collagen only, and five would have antibodies to native type II collagen with antibodies to one or more denatured collagens.

\section{CLASS OF ANTIBODIES TO TYPE II AND}

XI COLLAGENS

Thirty sera from anti-NBII positive patients were tested for IgG, IgA, and IgM anticollagen antibodies separately. All 30 sera had IgG antibodies to native type II collagen, while 25 had IgA and 12 IgM antibodies to this antigen. Similarly, 29 sera had IgG antibodies to denatured type II collagen, while 11 had IgA and 10 IgM antibodies to this antigen. Thus IgG antibodies were most common, but a large number of sera had IgA antibodies as well. The only correlation in antibody levels was shown between IgG antibodies to native and denatured type II collagen.

Nine sera had antibodies to native type XI collagen and 25 to denatured type XI collagen. Of the nine sera positive for antibodies to native type

Table 5 Comparison of antibody levels to denatured collagens in the RA patient groups

\begin{tabular}{|c|c|c|c|c|c|c|}
\hline \multirow[t]{2}{*}{ Collagen } & \multirow{2}{*}{$\begin{array}{l}\text { Upper limit of } \\
\text { normal }\end{array}$} & \multirow{2}{*}{$\begin{array}{l}\text { Highest level in } \\
\text { positive normal }\end{array}$} & \multicolumn{2}{|c|}{$R A$ anti-native II negative } & \multicolumn{2}{|c|}{$R A$ anti-native II positive } \\
\hline & & & Range & Median & Range & Median \\
\hline Denatured I & 255 & 341 & $259-790$ & 384 & $275-1532$ & 477 \\
\hline Denatured II & $199 \cdot 2$ & 229 & $200-990$ & 341 & $203-1397$ & 630 \\
\hline Denatured IX & $33 \cdot 6$ & 41 & $34-41$ & 37 & $39-186$ & 44 \\
\hline Denatured XI & $398 \cdot 3$ & 458 & $400-1300$ & 509 & $410-1018$ & 572 \\
\hline
\end{tabular}


Table 6 Calculated incidence of sera containing antibodies to native and denatured type $I, I I, I X$, and XI collagens in a rheumatoid arthritis patient population

\begin{tabular}{lcll}
\hline Collagen & Incidence (\%) & Collagen & Incidence (\%) \\
\hline Native II & $10 \cdot 0$ & Denatured II & $25 \cdot 5$ \\
Native I & $2 \cdot 0$ & Denatured I & $15 \cdot 6$ \\
Native IX & $2 \cdot 0$ & Denatured IX & $4 \cdot 4$ \\
Native XI & $2 \cdot 8$ & Denatured XI & $16 \cdot 8$ \\
\hline
\end{tabular}

XI collagen, one had IgM antibodies only, five had IgG antibodies only, and three had both IgG and IgA antibodies. Of the 25 sera with antibodies to denatured type XI collagen, 20 had IgG antibodies only, four had IgG and IgA antibodies, and one had IgG and IgM antibodies. Thus again IgG antibodies were predominant.

\section{Discussion}

From the incidences and patterns of antibodies to native collagens we conclude that the patients were not displaying a general reactivity to their collagens but a selective response. Antibodies to the denatured collagens were more widely distributed, occurring mainly in patients who also had antibodies to native type II collagen, but also in a substantial number of patients without these antibodies. Thus distinctive subsets of patients could be identified in terms of the patterns of antibodies to native and denatured collagens.

Antibodies to the different collagens may consist of antibodies to epitopes unique to each individual collagen or there may be antibodies to common epitopes. Antibodies to particular epitopes may be more important than others in the disease process. Therefore we are investigating the nature of the epitopes on the collagen molecule to which the antibodies seen in these patients bind and whether these subsets of patients can be distinguished either by the stage of their disease, the severity of their joint destruction, by their drug treatment, or by laboratory parameters.

The significance of these antibodies in the initiation or development of RA is unknown, though antibodies to native type II collagen seem to be more specifically associated with RA, whereas antibodies to denatured type II collagen occur more widely in the arthritides. ${ }^{5}$ Articular cartilage, which contains type II collagen as its major collagen type with both type IX and XI collagens as minor collagen components, is degraded in patients with RA. Antibodies to these collagens could be formed during breakdown of the cartilage as the collagens are exposed, and thus antibodies may be unrelated믐 to the initiation of the arthritis but may have a role in its development and be markers of the extent of $\overrightarrow{\vec{F}}$ existing or potential cartilage damage. Alterna- $-\frac{\vec{\sigma}}{\sigma}$ tively, immunity to collagens or a foreign antigen $\frac{}{0}$ with similar epitopes could produce antibodies $\overline{\bar{c}}$ which then could initiate the inflammatory processes $\widetilde{\Phi}$ in the joint. Recently, the ability of antibodies to type II collagen from a patient with RA to initiate an ${ }^{\infty}$ inflammatory arthritis in mice has been described. ${ }^{21} \vec{O}$

Whatever the role for these antibodies it probably $\overrightarrow{ }$ is not a universal one in all patients with RA. Many patients showed no evidence of any antibodies to these collagens whether native or denatured. Also? RA patients with antibodies to native type II collagen form a distinct genetic subset, ${ }^{22}$ though $\vec{\sim}$ they could not be distinguished on clinical groundsi from the other patients with RA. An individual N patient with antibodies to native type II collagen or음 another collagen at one stage in their disease, $\vec{\nabla}$ however, may be negative for these antibodies at another stage (personal observations). Such changes could be due to fluctuations in disease activity or the treatment.

Although these studies give us a very good idea $\& \mathrm{f}-\overrightarrow{0}$ the incidence of such antibodies in a RA population they are but a snapshot in time. Changing patte $\mathrm{s}$ of antibodies binding to different collagens and different epitopes in the same collagen molecule in individual patients may be a better reflection of changes in disease activity and progressions of the disease. Such studies are in progress.

This work was supported by grants from the Arthritis and Rheumatism Council. One worker (IC) was supported by the Bingham Trust. We wish to thank the pathology department at the Devonshire Royal Infirmary, Buxton, and Miss Angela Thompsonat the Manchester Royal Infirmary for collection of the bloodo samples and Mrs Doreen Ward for typing the manuscript.

\section{References}

1 Andriopoulos N A, Mestecky J, Miller E J, Bradley E L. Antibodies to native and denatured collagens in sera of patients with rheumatoid arthritis. Arthritis Rheum 1976; 19: 613-7.응

2 Clague R B, Shaw M J, Holt P J L. Incidence and correlation? between serum IgG and IgM antibodies to native type IL collagen in patients with chronic inflammatory arthritis. Ann Rheum Dis 1981; 40: 6-10.

3 Trentham D E, Kammer G M, McCune W J, David J R. Autoimmunity to collagen: a shared feature of psoriatic ando rheumatoid arthritis. Arthritis Rheum 1981; 24: 1363-9.

4 Clague R B, Moore L J. IgG and IgM antibody to native type IK collagen in rheumatoid arthritis serum and synovial fluidg Arthritis Rheum 1984; 27: 1370-7.

5 Stuart J M, Huffstutter E H, Townes A S, Kang A H. Incidence and specificity of antibodies to types I, II, III, IV and V collagen in rheumatoid arthritis and other rheumatic diseases as measured? by ${ }^{125}$ I-radioimmunoassay. Arthritis Rheum 1983; 26: 832-40. $\square$

6 Mestecky J, Miller E J. Presence of antibodies specific to cartilage-type collagen in rheumatoid synovial tissue. Clin ExpD Immunol 1975; 22: 453-6. 
7 Trentham D E, Townes A S, Kang A H. Autoimmunity to type II collagen: an experimental model of arthritis. J Exp Med 1977; 146: 857-67.

8 Morgan K, Clague R B, Shaw M J, Holt P J L. Native type II collagen-induced arthritis in the rat. I. Incidence and humoral response to collagen. Ann Rheum Dis 1980; 39: 285-90.

9 Stuart J M, Cremer M A, Kang A H, Townes A S. Collagen-induced arthritis in rats: evaluation of early immunological events. Arthritis Rheum 1979; 22: 1344-51.

10 Morgan K, Clague R B, Shaw M J , Firth S A, Twose T M, Holt P J L. Native type II collagen-induced arthritis in the rat: the effect of complement depletion by cobra venom factor. Arthritis Rheum 1981; 24: 1356-62.

11 Staines N A, Hardingham T, Smith M, Henderson B. Collageninduced arthritis in the rat: modification of immune and arthritic responses by free collagen and immune anti-collagen antiserum. Immunology 1981; 44: 737-44.

12 Courteney J S, Dallman M J, Dayan A D, Martin A, Mosedale B. Immunisation against heterologous type II collagen induced arthritis in mice. Nature 1980; 282: 666-8.

13 Trentham D E. Collagen arthritis as a relevant model for rheumatoid arthritis. Evidence pro and con. Arthritis Rheum 1982; 25: 911-6.

14 Burgeson R E, Hollister D W. Collagen heterogenicity in human cartilage: identification of several new collagen chains. Biochem Biophys Res Commun 1979: 87: 1124-31.
15 Ayad S, Abedin M Z, Grundy S M, Weiss J B. Isolation and characterisation of an unusual collagen from hyaline cartilage and intervertebral disc. FEBS Lett 1981; 123: 195-9.

16 Morgan K, Evans H B, Firth S A, et al. $1 \alpha 2 \alpha 3 \alpha$ collagen is arthritogenic. Ann Rheum Dis 1983; 42: 680-3.

17 Mayne R, von der Mark K. Collagens of cartilage. In: Hall B K, ed. Cartilage. Vol 1. New York: Academic Press, 1983: 181-214.

18 van der Rest M, Mayne R, Ninomiya Y, Seidah N G, Chretien $\mathrm{M}$, Olsen B R. The structure of type IX collagen. J Biol Chem 1985; 260: 220-5.

19 Jackson D S, Cleary E G. In: Glick D, ed. Methods of biochemical analysis. London: Interscience, 1967: 32-3.

20 Ayad S, Abedin M Z, Weiss J B, Grundy S M. Characterisation of another short-chain disulphide-bonded collagen from cartilage, vitreous and intervertebral disc. FEBS Lett 1982; 139: $300-4$.

21 Wooley P H, Luthra H S, Singh S K, Huse A R, Stuart J M, David C S. Passive transfer of arthritis to mice by injection of human anti-type II collagen antibody. Mayo Clin Proc 1984; 59: 737-43.

22 Klimiuk P S, Clague R B, Grennan D M, Dyer P A, Smeaton I, Harris R. Autoimmunity to native type II collagen-a distinct genetic subset of rheumatoid arthritis. J Rheumatol 1985; 12: 865-70. 